\title{
YOU, IN EMULATION
}

\author{
Brought to book.
}

\section{BY KATHRYN CRAMER}

$\mathrm{I}$ checked you out of the library. You were due back in two weeks for synchronization, but I kept you out much longer, running up huge fines. The librarian was very nice and didn't make me pay right away, but said that she had very little discretion; that the fines were set by the library system and your publisher.

I am a writer and I was looking for an acting teacher to help me improve how I read my work out loud. Although, of course, your publisher didn't tell me your real name, your bio on the package really spoke to me. I thought we would get along, and we did, from the very first moment that you were uploaded into my card slot.

Suddenly, there you were. It surprised me that you were my height. I'm not sure if that is an artefact of the software: virtual teachers scaled to the same size as their students, or whether you really are (or were) five foot six.

I was ready to work. I began to read aloud from the draft of my novel, and I could tell before you even said anything that the narrative voice just didn't work. She wasn't in the story, but aloof, above it all. This moment felt almost like telepathy, but I imagine it was accomplished by transmissions from the software of the emotional colouring of what you were about to say. I had written the story in the third person. But somehow with you sitting there listening to my voice as I read, I had to ask, "Who is this third person, anyway?" She is me, of course, but you looked at me with your blue eyes over your glasses, and I knew that was no answer.

The next day, you tried another angle. You had me sit down on the brown couch and told me to pretend I didn't know who I was or where I was. After I suggested a few solutions such as looking at my driver's licence to find out, I asked: "How does this scene not end in the emergency room?" Afterwards, I remembered that in that bio of yours I liked so much, a sort of artist's statement, you said, “The question 'Where am I?' is my preoccupation." You didn't remind me. Instead, you told me that you'd had an ischaemic event a while back that had left you unable to speak for a couple of days.

Your paintings hung on the walls of our virtual space. Quiet, expectant landscapes and abstracts involving brightly coloured rectangles. You said you couldn't paint any more. In between sessions, I sent you long e-mails, and you would reply in only

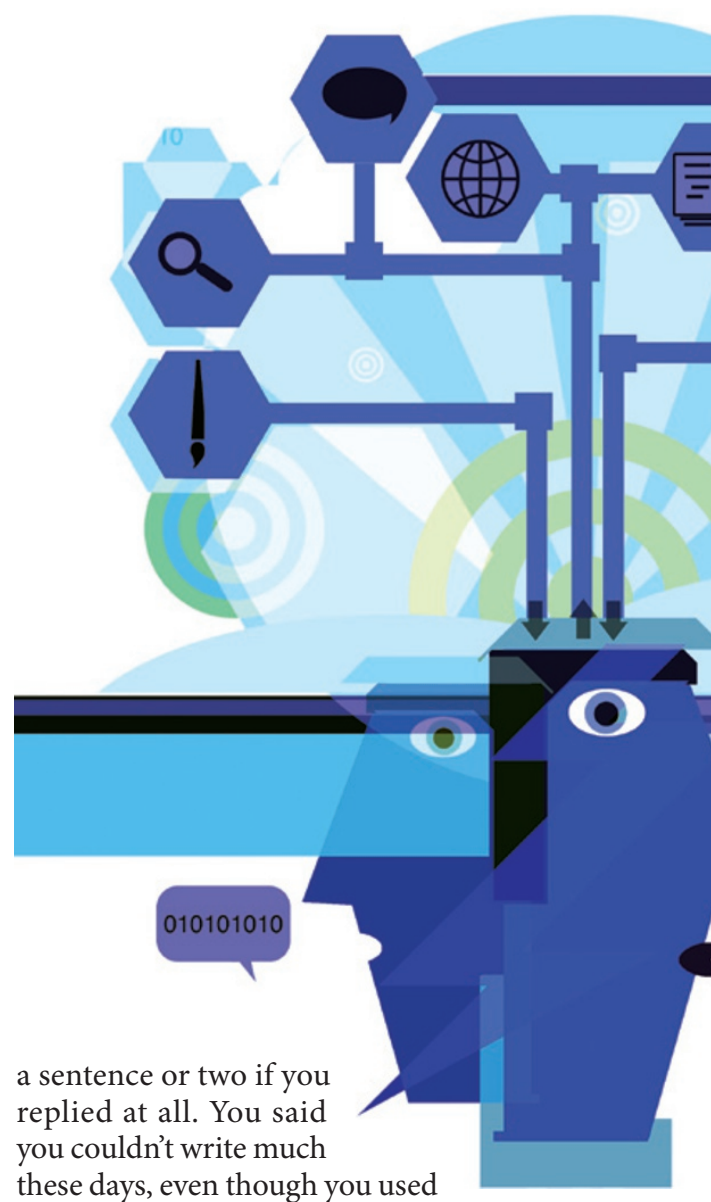

these days, even though you used to write whole books. The word agraphia came to mind.

At the two-week mark, what you were trying to teach me snapped into focus and I began to hear the narrative voice and to write and write and write, and when I read the words out loud, they were beautiful and pure and often when I read, you seemed on the brink of tears. The fines began to mount.

I wrote and wrote, and in between I worked out how to help, how to give you back writing and painting. First I write a sentence; you're next.

First I make a brush stroke, then you do. I took you hiking in the virtual woods and brought body paints. I told you to paint the sunset on my back as a sketch, and when we got back to our usual virtual space, you painted the sunset on canvas.

I would have kept you longer, except for the pain. Implants require synchroni- $\rightarrow$ NATURE.COM

Follow Futures on

Facebook at:

go.nature.com/mtoodm zation and constant upgrades. To keep you from being returned to the library, I had to stay away from the 